\title{
Philosophy of Religion: An Introduction
}

William L. Rowe

Wadsworth, Cengage Learning, 2007, $4^{\text {th }}$ Edition, 204 pp.

In the preface of the $4^{\text {th }}$ edition (p. xiii), Rowe relates the development of philosophy of religion in the 21st century with the ability of religious thinkers to demonstrate that religious belief supports rational arguments, growth in the understanding of non-Western religious traditions and continued interest in the problem of evil. He indicates his intention to address the reasons behind the development of this field of study. Rowe divides the topics of discussion into eleven chapters. In the introduction, the author indicates that philosophy of religion examines basic religious beliefs as well as the major conceptions of God that emerged in Western civilization, namely theistic ideas of God (p. 1-3).

Rowe starts the first chapter discussing the idea of God by mentioning the supposed accurate prediction by Bishop Robinson. According to Robinson, the idea of God is irrelevant to the needs of this generation. From pluralism, henotheism, monotheism, God 'up there' and 'out there, Robinson defends his infamous position. Concentrating on the idea of God as separate from the world and a spiritual, supremely good, all-powerful, allknowing and personal being, great theologians like Augustine, Boethius, Bonaventure, Avicenna, Anselm, Aquinas and Maimonides are mentioned as foundational figures. Exploring the attributes of God as omnipotent and perfect goodness, self-existent and eternal remains crucial in answering the question of the idea of God. Omnipotence in Aquinas' Summa Theologica is seen as God being able to do all things that are possible, where possibility is defined as relative possibility and absolute possibility. St. Anselm on the issue of self-existence observes three cases to consider: something is either explained by another, explained by nothing or explained by itself, wherein God inevitably exists within his own nature as he would not be supreme if his existence were due to something else. To establish divine separation from and independent of the world and the conception of God as an eternal being, Rowe explores the Judeo-Christian and Islamic conception of God which have it that the world is entirely distinct from God while the divine relates to the meaning of eternity as God is not bound by the law of time (p. 4-17). 
The second chapter of Rowe's book provides readers with the cosmological arguments explaining the first part of the argument while expanding on the concepts of a dependent-being and a self-existent being. After offering a historical overview of the cosmological argument, the self-existent being and the dependent being concepts further clarify the first part of this argument. The dependent being is explained as a being whose existence is accounted for by the causal activity of other things whereas the self-existent being remains a being whose existence is explained by its own nature. The Principle of Sufficient Reason (PSR) was first developed by St.Anselm, and later improved by Leibniz and Clarke. The PSR establishes that there must be an explanation for the existence of any being and of any positive fact. It also explains that not every being that exists can be a dependent being. However, criticisms exist, such as that which asserts that the collection of dependent beings is not itself a dependent being any more than a collection of stamps is itself a stamp, and that the collection itself must have a cause. Citing some errors on the part of critics, proponents continue to defend the argument. Complementing what was already discussed is the kalam (scholastic) theology argument, a cosmological argument which claims it is impossible for an actual infinite to exist, against Samuel Clark's version (p. 19-35).

The third chapter discusses the ontological argument that was credited to St. Anselm as the most important part of his Proslogium. This famous ontological argument posits God as the being 'than which none greater' is possible. It also adds that the existence of God in understanding means His existence in reality. It concludes therefore that God is greater (than which none greater is possible) since he both exists in understanding and reality. His reductio argument is supposed to guide the fool to the belief of God's existence. In a sharp criticism, Gaunilo, in his "On behalf of the fool," sought to prove that Anselm's argument was mistaken by postulating an example of an island, claiming instead he prefers to use the island against which none greater is found. In his reply to Gaunilo, Anselm insisted his reasoning applies only to God and to none else. However, Anselm could not say why his argument could not be applied to the island. Kant, with his sharp criticism of Anselm in the $18^{\text {th }}$ century, is by far the most famous critic of the argument. There are two parts of his claim: existence being quality or predicate and existence just like wisdom and unlike physical size, is a great-making quality or predicate. According to the objection, existence is not a predicate at all and since Anselm's third premise suggests a predicate it must be rejected. The third criticism of Anselm's argument questions the premise that God might have 
existed in reality, while the third objection rejects the very definition Anselm offered of God (p. 37-51).

Discussion in the fourth chapter centers on the old and new design argument, most famously explained by David Hume's Dialogue Concerning $\mathrm{Na}$ tural Religions. Rowe offers the example of a machine to clarify what Hume wrote: machines are produced by intelligent design, and as the universe resembles a machine, it follows that the universe was produced by intelligent design. The design argument seeks to answer the question of whether our universe was the result of an intelligent design. However, there arise questions as to whether the universe might actually be likened to a machine. William Parley rather compares the universe to a watch, claiming that every manifestation of design in the watch exists in the works of nature. The proponents of teleological arguments, like Parley, claim as the basis of their analogy that in the universe and machines we find many things and parts of things that are teleological systems, perceiving a human eye, for instance, as a teleological system. Rowe observes that the design argument seemed not able to explain why nature contains so many organisms whose various parts are so well adapted to their survival. Charles Darwin's theory of evolution provided a new hypothesis after the design argument lost some of its persuasive force. Meanwhile Behe, in disagreement with Darwin, proposed the mouse trap as an example of irreducible complexity and was supported in his claim by Kenneth Miller. As a theist, Miller, however, disagrees with Behe as a matter of belief, asserting that the universe is God's creation and that the big bang supports this notion (p. 61). David Hume, in his Dialogue Concerning Natural Religion, offers a classical attack against the design argument when he states not that the universe was too vast to resemble a machine, but that some vast parts of it still remain in chaos. In several of his arguments against design, Hume proposes that the argument cannot explain theism. The new design argument emerged in the $20^{\text {th }}$ century, and unlike the old design proponents, these new proponents do not start their arguments on the basis of the existence of living things. They rather ask of the condition of the universe and whether it is possible for living things to exist in it. Using the big bang theory, they claim the chance of existence is much less than one in a million. Miller claims that since humans can make observations only of their own universe, evidence cannot be obtained to determine the accuracy of the multiple universes hypotheses. That an alternative to a supernatural creator could exist remains a genuine possibility since we lack evidence for multiple universe hypothesis (MUH). Rowe dedicates a portion of this chapter to discuss the viability of the three arguments, i.e. cosmological, 
ontological and teleological, in establishing the existence of a theistic God. He concludes, however, that both cosmological and ontological arguments have failed to prove the existence of God. Though teleology helped much in that regard, it would have been more helpful if it had resorted to providing solid rational grounds for some aspect of the theistic God. However, the traditional arguments' failures to prove the existence of God should not be taken to mean they are worthless (p. 65).

The fifth chapter discusses religious and mystical experience. Although Rowe admits it is difficult to give an all-encompassing definition for religious experience, he references Schleiermacher's ideas, as examined by Rudolf Otto, that a religious experience is an experience wherein one is overcome by the feeling of absolute dependence. In other words, it is an experience in which one senses the immediate presence of the divine. The non-mystical experience senses the presence of the divine as a being distinct from oneself, while the mystical experience senses one's own union with a divine presence. The mystical experience can, he notes, be either an extroverted experience or introverted experience (p. 80). The main difficulty in religious experience is the distinction of divine being since mystics in various religions have myriads of experiences.

Faith and reason in the sixth chapter are explored by arguments concerning whether there are rational grounds to support the basic claims of theistic religions or not, and whether it is rational or irrational to accept religion on the basis of faith. Aquinas' and James' views on faith provide a fair introduction to faith-rationality debates surrounding religious beliefs. For Aquinas, reason is necessary, yet faith goes beyond rationality. A more radical view, contrasted with that of St. Aquinas, is that of James', who claims that faith is weak in relation to reason. Using Clifford's famous ship-owner ethic story, James establishes that the will to believe is an attack in itself against Clifford's view. Though he agrees with him to an extent, he parts ways with him by claiming that reason weighs a belief in terms of the evidence for or against it. James' religious hypothesis dictates that what is supreme is eternal and we are better off if we believe what is best is eternal. While some theists argue that arguments for the existence of God and the facts of religious experience provide sufficient rational grounds for believing in God, atheists on the other hand see the problem of evil as sufficient to disbelieve in His existence. Dedicating the rest of the pages to James' work on the defense of his hypotheses and passionate belief, Rowe puts forwards arguments by James on the defense of the right to believe as we wish concerning the theistic hypotheses. The theist according to him risks error due to his inadequate 
evidence supporting belief in God (p. 103). Plantinga, stressing the properly basic belief in God, claims that belief should be basic and, in the broader sense, evidence is applicable (p. 106).

In the seventh chapter, discussing the problem of evil, Rowe takes the reader through the earlier chapters, from all the subsequent arguments to establish the existence of God, while acknowledging that the most formidable of all those difficulties is that of the problem of evil. In this chapter, the two forms of the problem of evil are discussed: the evidential and logical forms. By the logical form several traditional premises were discussed, agreed to and disagreed to with the free will defense (p. 118). The evidential problem seeks to justify the problem of evil by postulating that suffering may lead to a greater good. Rowe agrees that the logical form seemed not a problem for the theists but the evidential form proponents, who argue that God does not exist, appears to be plausible. The skeptical theists' response to the evidential form proposes that the reason the human mind is baffled by this state of affair is simply because it does not know enough. Stephen Wykstra, a skeptical theist, cites the example of a dog in a garage to explain the issue more clearly (p. 122). Theodicy then comes with an attempt to explain the probable purposes of God for permitting the profusion of evil in our world. Hick sees that suffering is necessary to ensure compassion, sympathy and even deterrence. Moore also provides a procedure which he proposes as the ideal procedure for theists to follow. (p. 128).

The position of miracle and its impact in the modern world form the basis of the $8^{\text {th }}$ chapter. This chapter is concerned with whether it remains possible to believe in miracles and whether it is reasonable to believe that a miracle has truly occurred. Bultmann disagrees with the compatibility of miracle and science. To him, a modern world view leaves little or no room for spirits. Rowe agrees with Bultmann that it is more difficult to believe in miracles than it once was. Hume's definition of miracle as a transgression of a law of nature by the volition of a deity is objected to by the likes of C. D. Broad, who does not agree that a miracle has violated the laws of nature. But problems still remain, as the conditions an event must satisfy to constitute a genuine miracle are not clear, as well as whether it is ever reasonable to believe that a genuine miracle has occurred as technology and science are creating more disbelief in miracles (p. 145).

The ninth chapter addresses the myths and realities of life after death. Rowe brings into this chapter ancient ideas about death which are Platonic and Homeric. While the Homeric believed in the immortality of humans, Platonic reserved immortality to the gods only (p. 148). The final form of 
belief in the idea of life after death is associated with the issue of resurrection of the body. The conceptual and factual questions seek to probe the idea of the survival of the human person or the soul after death. While conviction asks whether the conviction is meaningful, the factual asks whether the conviction is true. The philosophical argument on the immortality of the soul rests on the Platonic view that the soul is immaterial and a purely spiritual substance. The scientific argument of the proxy sitting in the Super Etrasensory Perception Hypothesis (p. 157) explains human persons' survival of bodily death with Betrand Russel also setting the general theme of the scientific argument against immortality. The theological argument relies on the belief that a theistic God exists. Rowe, however, sums it up by saying that unless a good reason is provided to accept theism, there exists no reason to believe in the personal survival after bodily death (p. 160).

On the issues of predestination, divine knowledge and human freedom in the $10^{\text {th }}$ chapter, Rowe explains that before eternity God knew whatever would come to pass, including our free choices and acts that were not predetermined. He discusses the philosophical and theological reflections of the freedom of will which consists of doing what one wants or chooses to do. John Locke postulates two men in rooms with different conditions (p. 164). On the power to do otherwise, it is contested also that human freedom is inconsistent with divine predestination. The problem lies in divine foreknowledge and human freedom. Rowe admits there is no absolute solution to this problem (p. 166). On human freedom it is agreed that an inadequate idea of human freedom makes us unaware of exactly how free or less free we are. Rowe uses the time logic with other examples to explain 'what is in human power' as 'that which has not happened. He also explains 'what is not in human power' as 'that which is in the past'. Ockham maintains that facts about divine foreknowledge, which are used as the basis for denying human freedom, are facts about the past though not simply about the past. However, defining God as eternal and infinite sets Him as timeless and existing outside of time, as the famous philosopher Boethius says.

The $11^{\text {th }}$ chapter, which marks the last chapter, discusses how a particular religion should or may view other religions in a world of many religions. Discussing this, exclusivism, inclusivism and pluralism are brought to light. Pluralism against all odds as promoted by Hick, though conceptualized long before him by Tillic, seems to validate all religions as parts of the whole universal being. Hick propounds the three blind men and the mighty elephant parable to explain his point. Inclusivists, on other hand, rather consider nonChristians in other places where the gospel is yet to reach as part of divine 
salvation due to their inability of reaching the gospel. The exclusivist holds the belief that truth lies within her own religion and that any other religion holding a different or opposing view is false. The three sections in their quest to define themselves in the world of many religions rather end up defining the fate of other religions in their dogmas.

The remainder of the pages provide a glossary of important concepts as well as references for further reading. In general, the book is intended to be easily understood regardless of one's background. The textbook introduces one to debates in philosophy of religion in a comprehensive way. Whether it is the philosophical proofs for God's existence or the use of reason to evaluate faith claims, the major points in the philosophy of religion are covered in this excellent textbook. Rowe, despite the bulky nature of the subject matter, tries to cover the crucial and the nitty-gritties in less than 222 pages. Rowe's excellent way of providing questions for review at the end of every chapter speaks volumes about his preparedness to engage his readers. The language used is very easy to understand and the logic together with the practical examples he cites make his analysis very clear.

Though in many cases Rowe makes use of the Christian faith due to his inclination to it, he could have been more open and general as far as philosophy of religion is concerned by covering the Asiatic religions in the topics he raises and discusses. Beside that, Rowe, in his discussion of the scholastic theology (Kalam), offered more general rather than specific explanations. In many cases Muslim philosophers like the peripatetic philosophers in the likes of Ibn Sina were also overlooked. In the case of the problem of evil, the contributions of $\mathrm{Al}$ Ghazali should have been mentioned. While I agree that most Muslim philosophers have roots in Greek philosophy, discussing their thoughts could have expanded the discourse and provided enlightening and thought-provoking arguments.

\section{Mohammed Hashiru}

Mphil student of Philosophy of Religion, Sakarya University 